\title{
A spectrum of verocytotoxigenic Escherichia coli
}

There appears to be an increasing prevalence around the world of both sporadic cases and outbreaks of human infection associated with verocytotoxigenic Escherichia coli (VTEC). VTEC of serotypes O157:H7 and $\mathrm{O} 157: \mathrm{H}^{-}$are most frequently reported from these cases, but many other $E$. coli serotypes have also been encountered. Several of these $[1,2]$ were recorded before the first report of outbreaks caused by strains of serogroup 0157 in 1982 [3]. VTEC of serogroup 0157 generally belong to a clone that has a number of unusual features, including an inability to ferment sorbitol and to produce $\beta$-D-glucuronidase, which most other $E$. coli are able to do. These characteristics make them comparatively easy to isolate and characterise, and specific media have been developed to facilitate the isolation of these strains from patients.

Studies in Australia have demonstrated that a wide variety of VTEC serotypes are associated with infection [4]. When the first outbreak occurred in 1995, the strains isolated were predominantly VTEC $0111: \mathrm{H}^{-}$, although a number of other serotypes, including $\mathrm{O} 157: \mathrm{H} 7$ and $\mathrm{O} 157: \mathrm{H}^{-}$were also found [5]. Australia is by no means unique in isolating nonO157 VTEC from patients and the environment. Moreover, the experiences of the Australian 0111: $\mathrm{H}^{-}$outbreak have shown that if due care had not been taken, it may well have been described as an
O157 outbreak [6] and other reported outbreaks might similarly have been wrongly attributed.

From over 10 years experience of operating an E. coli reference laboratory with a full set of $E$. coli $\mathrm{O}$ and $\mathrm{H}$ antisera, it has been possible to establish a unique data set of VTEC serotypes in Australia. Realising that toxigenicity is unlikely to be restricted to the VTEC O157 clone, or just a few serotypes, we have kept an open mind on the likelihood of encountering other toxigenic strains. As a result, various VTEC serotypes from both human and environmental sources have been recognised. Apart from testing for the presence of one or both of the verocytotoxins, the strains were also tested for the presence of enterohaemolysin, which is considered to be a virulence factor associated with VTEC.

A selection of the strains that have recently been characterised are listed in Table 1. As can be seen, a wide spectrum of $E$. coli serotypes other than accepted VTEC types, such as the O157 and O111 serogroups, produce verocytotoxin, with or without enterohaemolysin. Serotypes with the 0157 or $\mathrm{H} 7$ antigens that possess neither the verocytotoxin nor the enterohaemolysin are also found, but are not associated with disease. These findings indicate that VTEC serotypes $\mathrm{O} 5: \mathrm{H}^{-}$and $\mathrm{O} 91: \mathrm{H}^{-}$should be considered as pathogens regardless of source, as strains isolated

Table 1. Verocytotoxin and enterohaemolysin production of a selection of strains of $E$. coli recently isolated in Australia

\begin{tabular}{|c|c|c|c|c|c|}
\hline \multirow[b]{2}{*}{ Serotype } & \multirow[b]{2}{*}{ Verocytotoxin } & \multirow[b]{2}{*}{ Enterohaemolysin } & \multicolumn{2}{|c|}{ Isolated from } & \multirow[b]{2}{*}{ Associated with HUS } \\
\hline & & & man & environment & \\
\hline $\mathrm{O} 157: \mathrm{H7}$ & + & + & + & + & Yes \\
\hline $\mathrm{O} 157: \mathrm{H}^{-}$ & + & + & + & + & Yes \\
\hline $\mathrm{O} 111: \mathrm{H}^{-}$ & + & + & + & + & Yes \\
\hline $\mathrm{O} 48: \mathrm{H} 21$ & + & + & + & - & Yes \\
\hline $\mathrm{O} 128: \mathrm{H} 2$ & + & + & + & - & Yes \\
\hline $\mathrm{O} 5: \mathrm{H}^{-}$ & + & + & + & + & Yes \\
\hline $\mathrm{O} 5: \mathrm{H}^{-}$ & + & - & - & + & Yes \\
\hline $\mathrm{O} 91: \mathrm{H}^{-}$ & + & + & + & + & Yes \\
\hline O130:H11 & + & + & + & - & Not reported \\
\hline $\mathrm{O} 116: \mathrm{H} 21$ & + & + & + & + & Not reported \\
\hline O113:H21 & + & - & + & + & Yes \\
\hline $\mathrm{O} 153: \mathrm{H}^{-}$ & + & + & - & + & Not reported \\
\hline O69:H8 & + & - & - & + & Not reported \\
\hline $\mathrm{O} 137: \mathrm{H} 41$ & + & - & - & + & Not reported \\
\hline O169:H28 & + & - & - & + & Not reported \\
\hline O128:H16 & + & - & - & + & Not reported \\
\hline
\end{tabular}

HUS, haemolytic uraemic syndrome 
from patients and the environment have been associated with cases of haemolytic uraemic syndrome (HUS) in Australia and elsewhere. VTEC serotypes $\mathrm{O} 130: \mathrm{H} 11, \mathrm{O} 116: \mathrm{H} 21$ and $\mathrm{O} 153: \mathrm{H}^{-}$that produce both cytotoxin and haemolysin are most probably pathogens, although they have not yet been reported in cases of HUS. Serotypes of $\mathrm{O} 5: \mathrm{H}^{-}$and $0113: \mathrm{H} 21$ that lack the enterohaemolysin have been associated with HUS and thus appear to be pathogenic. Other VTEC serotypes that lack the ability to produce enterohaemolysin (O69:H8; O137:H41; O169:H28; and O128: H16) have presently been isolated only from environmental samples. They may have the potential to cause human disease, but on present knowledge the case is not proven. Strains with the $\mathrm{O} 157$ or $\mathrm{H} 7$ antigen, but which produce neither verocytotoxin nor enterohaemolysin, can be isolated from patients, but should not be considered as pathogens.

The serotype O48:H21, which has only once been isolated in Australia, from a very severe case of HUS [7] had at that time not been reported elsewhere. If this serotype had only been isolated from some environmental source such as animal faeces, food etc., its pathogenic significance might have been overlooked. It has since been reported as a pathogen from a number of countries.

These results and a close examinination of the world literature clearly show that, while strains belonging to the VTEC clone $\mathrm{O} 157: \mathrm{H} 7 / \mathrm{H}^{-}$are important, they are most certainly not the only VTEC in our environment that can cause human disease. There are plenty of strains belonging to various serotypes, which are potential pathogens, and which, in some cases, have actually been shown to be associated with disease. Australia has been considered by some as being unique in having such a variety of enterohaemorrhagic E. coli serotypes [8]. Although this may be true, it is more likely that these non-O157 VTEC have been detected by having maintained an open mind about their possible involvement in infection.

Unfortunately, non-O157 strains do not have a unique set of biochemical markers, which makes their isolation much more difficult, especially as they are often present in small numbers. However, difficulty in recognising non-O157 VTEC isolates does not mean that the attempt should not be made. The recent description of the use of simple tests for the production of enterohaemolysin [9], which most VTEC, regardless of serotype, produce may well lead the way to the isolation of more non-O157 VTEC. Human ingenuity will no doubt come up with solutions to these problems and it will become possible to disentangle the true pathogens from other $E$. coli within this spectrum of VTEC serotypes.

KARL A. BetTELheim National Escherichia coli Reference Laboratory, Victorian Infectious Diseases Reference Laboratory, Locked Bag 815, Carlton South, Victoria 3053, Australia. E-mail: kabsm@jolt.mpx.com.au

\section{References}

1. Wade WG, Thom BT Evans N. Cytotoxic Enteropathogenic Escherichia coli. Lancet 1979; 2: 1235-1236.

2. Wilson MW, Bettelheim KA. Cytotoxic Escherichia coli serotypes. Lancet 1980; i: 201.

3. Riley LW, Remis RS, Helgerson SD et al. Hemorrhagic colitis associated with a rare Escherichia coli serotype. New Eng $J$ Med 1983; 308: 681-685.

4. Goldwater PN, Bettelheim KA. The role of enterohaemorrhagic E. coli serotypes other than $\mathrm{O} 157: \mathrm{H} 7$ as causes of disease. In: Karmali MA, Goglio AG (eds) Recent Advances in Verocytotoxin-producing Escherichia Coli Infections. (Excerpta Medica International Congress Series 1072). Amsterdam, Elsevier. 1994: $57-60$.

5. Cameron S, Walker C, Beers M, Rose N, Anear E. Enterohaemorrhagic Escherichia coli, outbreak in South Australia associated with the consumption of Mettwurst. Comm Dis Intell 1995; 19: 70

6. Goldwater PN, Bettelheim KA. An outbreak of hemolytic uremic syndrome due to Escherichia coli 0157:H7: or was it? Emerg Infect Dis 1996; 2: 153-154.

7. Goldwater PN, Bettelheim KA. Hemolytic uremic syndrome due to shiga-like toxin producing Eschericinia coli O48:H21 in South Australia. Emerg Infect Dis 1995; 1: 132-133.

8. Desmarchelier PM. Enterohemorrhagic Escherichia coli - the Australian perspective. J Food Protect 1997; 60: 1447-1450.

9. Bettelheim KA. Identification of enterohaemorrhagic Escherichia coli by means of their production of enterohaemolysin. $J$ Appl Bact 1995; 79: 178-180. 